OPEN ACCESS

Edited by: Amy Ahim Kim, University of Washington,

United States

Reviewed by:

Basak Gucyeter,

Eskişehir Osmangazi University,

Turkey

Stanley King,

Retired, Vancouver, Canada

*Correspondence:

Don Alexander

don.alexander@viu.ca

Specialty section:

This article was submitted to

Sustainable Design and Construction,

a section of the journal

Frontiers in Built Environment

Received: 10 August 2019

Accepted: 14 April 2020

Published: 12 May 2020

Citation:

Alexander D and Wydeman B

(2020) The Intersection

and Divergence of New Urbanism

and Environmental Psychology: An

Exploration. Front. Built Environ. 6:61.

doi: 10.3389/fbuil.2020.00061

\section{The Intersection and Divergence of New Urbanism and Environmental Psychology: An Exploration}

\author{
Don Alexander* and Bronwyn Wydeman \\ Department of Geography/Master of Community Planning Program, Vancouver Island University, Nanaimo, BC, Canada
}

Using the limited literature comparing the findings of New Urbanism and environmental psychology as to the desirable characteristics of neighborhoods and resident satisfaction, and with a focus on an urban inner-city neighborhood in Vancouver (Canada) built in the mid-to late-1970s, this paper focuses on the similarities and differences of two orientations to the built environment, their respective strengths and weaknesses, and what each can learn from the other. It suggests that the planners and architects who planned and designed the neighborhood had an advanced grasp of community-building principles that are still relevant today, and New Urbanism and environmental psychology are capable of learning from them.

Keywords: new urbanism, environmental psychology, comparing the two orientations, False Creek South, learning from a successful urban community

\section{INTRODUCTION}

New Urbanism, a planning and architectural design philosophy that came to prominence in the early 1980s, and environmental psychology, which emerged as a distinct branch of psychology in the late 60s, both have much to say about the kinds of environments, built and natural, that contribute to human well-being. New Urbanism was a reaction in large part to the automobile-dominated landscapes of the 1940s and beyond and, despite its name, has sought to resurrect many of the traditional features characterizing cities and small towns before the era of the car. It is very broad in scope in that it looks at a range of scales from the regional down to the site and building scale. In addition to promoting human well-being, it is also concerned with ecological sustainability, social justice, and economic efficiency (Congress for the New Urbanism and Talen, 2013).

Environmental psychology evolved from dissatisfaction with the ever developing built environment and was conceived to better understand the relationship between people and their environments (Garling, 2014). Environmental psychologists explore various topics such as; the role of nature in stress reduction, what influences environmental attitudes and behaviors, and factors that foster sense of community, with the intention to identify what types of environments best promote human well-being (Gifford et al., 2011).

Our hypothesis is that there are significant commonalities and differences between New Urbanism and environmental psychology that can be identified and used in the field of community planning to create more ideal neighborhoods. Environmental psychology and New Urbanism are parallel fields that are missing an opportunity to work together; the goal of this article is to add to the literature that promotes forming a symbiotic relationship between the two disciplines. This article uses a case study of a community whose design largely predates the rise to prominence of $\mathrm{New}$ 
Urbanism and environmental psychology, ${ }^{1}$ but which we feel would score high on their respective criteria for human and social well-being. The community chosen is False Creek South in Vancouver, Canada, and it was largely designed based on the "pattern language" philosophy annunciated by architect Christopher Alexander (Alexander et al., 1978; Hardwick, 1994).

\section{EXPLORING EXISTING NEW URBANISM AND ENVIRONMENTAL PSYCHOLOGY RESEARCH}

Not much has been written about where these two perspectives overlap or what each might learn from the other. We have identified two relevant articles. One is "New Urbanist and Standard Suburban Subdivisions: Evaluating Psychological and Social Goals" by Brown and Cropper (2001). The other is "Physical and Psychological Factors in Sense of Community: New Urbanist Kentlands and Nearby Orchard Village" by Kim and Kaplan (2004).

The article by Brown and Cropper (2001) looks at two communities in Utah, one New Urbanist and the other a standard subdivision. There are significant differences in how each is laid out. The New Urbanist community has smaller lots, a greater diversity of housing types and densities (including rental suites as part of houses), and where parking is accessible only from the rear of the lots via alleyways. There is abundant green space and the community is pedestrian-oriented. By contrast, the standard subdivision has larger lots, garages in the front, no sidewalks, but has a clubhouse with a swimming pool, which is the main venue for community interaction.

Based on survey research, the authors discovered that the residents in both communities are generally content with the physical form of their respective neighborhoods and report a fairly strong sense of community. While those living in the New Urbanist community are very appreciative of its green space and pedestrian orientation, they express concern about the increasing crowding of the alleys with cars as the rear setbacks are such that, even with garages, additional cars are visible and sometimes jut out into the lanes. Despite the walkability of the neighborhood, there is no apparent reduction in the number of vehicles per household. The sense of community is not significantly stronger in the New Urbanist community.

The second article, by Kim and Kaplan (2004) is of special interest because Kim is prominent in the fields of architecture and urban design, including New Urbanism, and Kaplan is one of the leading innovators and researchers in environmental psychology. Like the previous authors, their article compares two communities, this time the New Urbanist community of Kentlands, Maryland and the standard subdivision of Orchard Grove, Maryland. Their findings, based on surveys conducted with residents, showed a significantly higher reported sense of

\footnotetext{
${ }^{1}$ The antecedents of environmental psychology go back to the early 20th century and took further shape in the writings of Rachel and Stephen Kaplan in the late 1960s. This was also the time when the first journals in the field appeared. However, the field did not emerge into broader professional and academic awareness until considerably later (Gifford, 2014a).
}

community in Kentlands than in Orchard Grove. The authors suggest a certain degree of self-selection may account for that, with the Kentlands residents seeking a stronger sense of community, and the Orchard Grove residents seeking more privacy, though community wasn't absent in Orchard Grove. However, they concluded that the stronger sense of community in Kentlands could not be reduced to self-selection factors based on their statistical analysis and cross-referencing of survey data. Residents from both communities self-reported being relatively happy.

\section{CASE STUDY: FALSE CREEK SOUTH, VANCOUVER - VISION AND REALITY}

The present article fills a gap by explicitly looking at an innercity, as opposed to a suburban, neighborhood and examines where New Urbanism and environmental psychology overlap and where they diverge. The subject of the case study is a unique community in Vancouver, Canada: False Creek South. When False Creek South was planned and built, New Urbanism did not explicitly exist, but we argue that its form and structure prefigured many New Urbanist principles. In fact, there is still much to learn, for both New Urbanists and environmental psychologists, from the philosophical orientation of the planners and architects who designed the neighborhood. We will examine the qualities of the neighborhood and how these relate to the principles of the urban planning and architectural philosophy known as New Urbanism and the principles espoused by environmental psychology with respect to healthy neighborhoods for residents.

\section{Background to False Creek South}

False Creek South in Vancouver, Canada was planned and developed in the 1970's on 55 hectares (136 acres) of predominantly City-owned land. It was an era of progressive and enlightened planning and design thinking at all levels of government (Hardwick, 1994; Alexander, 2020). Its development was largely guided by architect Christopher Alexander's "pattern language" (Hardwick, 1994; Alexander et al., 1978). ${ }^{2}$ The planning firm, Thompson, Berwick, Pratt, and Partners produced a series of documents for the City that outlined what patterns should be implemented for the neighborhood. These included patterns relating to:

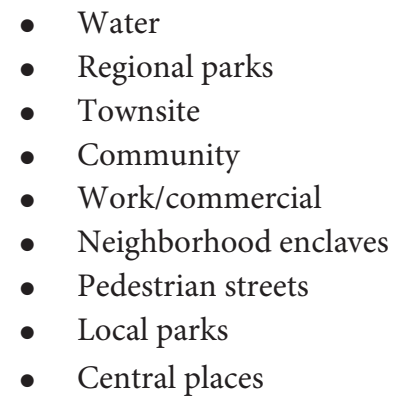

- Housing

- Built form

- $\quad$ Roads and parking

- Community facilities

- Multiple dwelling units

- Private outdoor space

- Room for future change and adaptation (Thompson et al., 1974)
- Open space

${ }^{2}$ While Alexander's "pattern language" was not given full published expression until 1978, it was circulating in architectural and planning circles a number of years before. In this connection, see also Alexander (1969). 
Many of the specific patterns they articulated under each heading overlap. Moreover, their description of the rationale for these patterns is instructive:

\begin{abstract}
We have examined what problems will arise when the parts of our city are not shaped to fit human activity. We have tried to anticipate where these failures might occur, making the False Creek area less livable and less successful. To do this we have separated the problems, isolated the conflicting tendencies and attempted to come to some resolution. This is then stated as a prescription, what should be done to avoid the problem.... We call each of these prescriptions patterns.... In a pattern, the problem and pattern are discussed in generic terms. In this way they can give rise to a wide variety of applied solutions (Thompson et al., 1974, p. 1).
\end{abstract}

The patterns enumerated are far too numerous to review and summarize here, but some of the essential ones include: urban enclaves, a pedestrian activity focus, inter-community public transit, adaptable communities (allowing for future change), reference points, a local shop every 1,500 feet (457 $\mathrm{m})$, and having the community bounded by the large and small bays of False Creek, the adjacent water body (City of Vancouver Planning Department, 2017).

In addition to the influence of Alexander's "pattern language," there were a number of high-caliber architects and planners involved in the neighborhood's development, including those, like Stanley King, who actively engaged members of the public in ranking desirable urban attributes and activities based on a series of images exhibited in public space, and who held public meetings where possible future residents could express their opinions about the kind of environment they wanted to live in and the activities they wanted to carry out. In total, over a thousand individuals were engaged in the process. Even children were involved in designing their future school and desired playground (King, 2020).

\section{The Patterns of False Creek South}

The enclaves (see Figure 1) were to be nested areas: clusters of buildings with central courtyards with an inward focus $\sim 500$ feet $(152 \mathrm{~m})$ in diameter and with populations of up to 700 people. These were intended to provide both a certain measure of privacy and territorial space for the residents living in them, but also a focal point for social interaction (Thompson et al., 1974). The focus of the neighborhood was on the pedestrian realm with linked pedestrian spaces meant to promote communal interaction and avoid domination by cars. Pedestrians were afforded reference points and pleasing natural vistas every few minutes-both as navigational aids and for esthetic purposes. Public transit was in place before people started moving in so that they would be able to access other parts of the city easily without relying on their vehicles.

The neighborhood was laid out in a fashion that enabled it to accommodate new growth and future change, and where all residents were able to access local shops arranged throughout (Ball, 2014). The neighborhood was also supplied with abundant green space in the form of a central park Charleson Park, with a forested berm to protect residences from car noise, a waterfall (from city water), an engineered stream and wildlife pond, dog use areas, a children's playground, a picnic area, and a community garden (added later). In addition, a vegetated walkway was installed over the busy arterial to the adjacent neighborhood of Fairview Slopes. To this day, $36 \%$ of the neighborhood consists of open space, including a sea wall and linear park leading to the lively and popular Granville Island market and crafts precinct in one direction, and to the diverse and growing neighborhood of Southeast False Creek/Olympic Village in the other (Alexander, 2020).

One area where False Creek South has not fully succeeded is providing mixed use buildings and walkable commercial venues. Originally, every resident was supposed to be within 1,500 feet $(457 \mathrm{~m})$ of a store (City of Vancouver Planning Department, 2017). There is a small commercial district in Leg-in-Boot Square, but with its only grocery store now closed and only non-essential stores remaining, the square does not provide the neighborhood with fundamental amenities.

Although the distribution of neighborhood businesses has not lived up to initial expectations, new opportunities have arisen. Granville Island, a public market and arts and culture precinct which False Creek South surrounds, increases in popularity as it provides a source of fresh foods, unique entertainment and retail opportunities, and houses the neighborhood community center. New commercial areas have emerged in the nearby neighborhood of Southeast False Creek/Olympic Village - with an all-category drug store, grocery store, bakery, and liquor store - and along Cambie Street up to Broadway Avenue West, with two grocery chains and several big box outlets.

Another limitation that has emerged over the years is that the enclaves have not necessarily provided the right mix of privacy and conviviality. Some residents have suggested that they want more privacy than the enclaves afford, and indeed spend considerable time on their private balconies and patios, rather than mixing in the semi-communal enclave spaces (Vischer Skaburskis Planners, 1980; Vischer, 1986). However, the enclaves have proven to be sheltered play spaces for children and provide an opportunity for parents and neighbors to monitor kids' activities, and their success as social spaces depends a lot on their individual design (King, 2020). Moreover, the pedestrian orientation of the neighborhood guarantees serendipitous encounters with neighbors and acquaintances, something that is often remarked upon by residents (King, 2020). This is reinforced by the fact that its parks and open spaces are not monopolized by any one age group (Ball, 2014; Gifford, 2014b).

One of the founding principles of the neighborhood was that it was to be diverse in terms of incomes and tenure types - in fact, it was supposed to reflect the income distribution of the Greater Vancouver region: one-third upper-income, one-third middle-income, and one-third lower-income (Alexander, 2020). Post-occupancy evaluations suggest that it was successful in this regard (Vischer Skaburskis Planners, 1980; City of Vancouver Planning Department, 1989). It is also characterized by an astonishing diversity of tenure types: strata, housing co-ops, nonmarket rentals, and social housing. In fact, it features the largest 


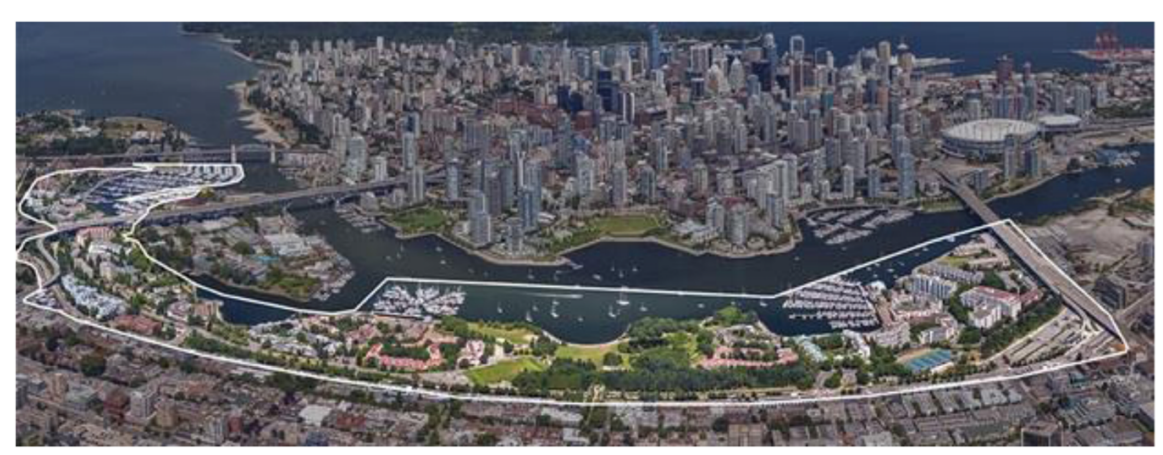

FIGURE 1 | False Creek South (source: City of Vancouver; reprinted with permission).

concentration of co-operative housing units in the province of British Columbia (Alexander, 2020).

The ethnic make-up of the City of Vancouver and region has changed considerably since the mid-to-late 70s' when False Creek South was being developed, and the neighborhood does not fully reflect this change in ethnicity, as it has remained largely white. Contributing to the lack of diversity is that many of the original residents have chosen to remain and "age in place" because of the perceived quality of life - it was voted the "best" neighborhood in the city by Vancouver Magazine (2016). Thus, the age of residents is higher than the city or regional average (City of Vancouver Planning Department, 2017).

\section{NEW URBANISM, ENVIRONMENTAL PSYCHOLOGY, AND FALSE CREEK SOUTH}

In the following section, we have organized a discussion of the features for comparison between New Urbanism and environmental psychology, as refracted through the example of False Creek South. These features include natural features; public space; environmental threats; maintenance and esthetics; architecture and design; building types and mixed uses; walkability; amenities; peace and quiet; safety/passive surveillance; and diversity. We have based our discussion on a number of sources: Congress of New Urbanism (n.d.); Congress for the New Urbanism and Talen (2013); New Urbanism (n.d.) and environmental psychology, Gifford et al. (2011); Gifford (2014a; 2014b).

\section{Natural Features}

One of the guiding attributes of New Urbanism is its emphasis on abundant green space as it is believed that it reduces stress for city dwellers and provides opportunities for diverse forms of recreation for people of all ages. Environmental psychology is founded on theories such as attention restoration theory that speak to our innate need to be in nature and that natural environments can increase physical, social, and mental health (Gifford, 2014b). False Creek South is a significant example of this facet of both New Urbanism and environmental psychology as more than one third of the neighborhood is park and green space, with mature forest and water features that cater to both humans and wildlife.

\section{Public Spaces}

For New Urbanists, public spaces are the spine around which communities should be organized. They are often punctuated with civic monuments or structures to foster sense of place and civic pride, are designed to promote active transportation through walkability and access and serve as places for community events and random social encounters. Although the role of public spaces in environmental psychology corresponds with New Urbanism, their importance comes from the influence public spaces have on fostering social interaction and decreasing stress. From first-hand experience of having lived there, one of the authors knows how restorative a walk in the park or along the seawall can be and how easy it is to run into neighbors or make new acquaintances.

The public spaces in False Creek South were designed to highlight constantly changing vistas, to enhance connectivity for pedestrians and cyclists, and to limit access for cars. The neighborhood surrounds Granville Island, a lively market and cultural precinct with an active street life. However, another public gathering place that was expected to be successful - the much smaller Leg-in-Boot Square - never lived up to its believed potential for a variety of reasons. The neighbors in its adjacent mid-rises have been afraid of noise that might result from the use of the public space, and none of the businesses along its periphery are of the kind that would "animate" it. However, overall, the programmatic characteristics of the two perspectives regarding public space are borne out in the neighborhood.

\section{Healthy Environments/Environmental Threats}

New Urbanism doesn't explicitly address environmental threats except in advocating for eco-friendly technologies and less reliance on non-renewable energy sources. It presumes there will be no environmental threats as many New Urbanist communities to date have been built on greenfield sites. This aspect could be more explicitly underlined since new neighborhoods will increasingly be developed through infill and 


\begin{tabular}{|l|c|c|c|}
\hline Features & New Urbanism & $\begin{array}{l}\text { Environmental } \\
\text { Psychology }\end{array}$ & False Creek South \\
\hline Natural Spaces & & & \\
\hline Public Spaces & weak & & \\
\hline $\begin{array}{l}\text { Healthy } \\
\text { Environments }\end{array}$ & & & \\
\hline $\begin{array}{l}\text { Maintenance and } \\
\text { Cleanliness }\end{array}$ & & & \\
\hline $\begin{array}{l}\text { Smaller Scale } \\
\text { Architecture and } \\
\text { Design }\end{array}$ & & & \\
\hline $\begin{array}{l}\text { Mixed Use Building } \\
\text { Types }\end{array}$ & & & partial \\
\hline \begin{tabular}{l} 
Walkability \\
\hline Amenities
\end{tabular} & & & \\
\hline $\begin{array}{l}\text { Feelings of } \\
\text { Relaxation }\end{array}$ & & & \\
\hline Feelings of Safety & & & \\
\hline Resident Diversity & & & \\
\hline
\end{tabular}

FIGURE 2 | A comparison of desired attributes in new urbanism and environmental psychology and their presence in False Creek South.

brownfield redevelopment with their legacies of toxic residues. Environmental psychology insists that neighborhoods should be free from "technological threats" such as noxious industries and power plants. False Creek South is not adjacent to any noxious industries or threats and has generally good air quality. The neighborhood replaced a dirty industrial precinct, so this was a step forward in terms of environmental quality for the area. Water quality is occasionally compromised by effluent from combined storm water and sewer overflows, and the adjacent water body of False Creek is not considered safe to swim in because of occasional high counts of $e$ coli bacteria (Griffin, 2019).

\section{Maintenance and Cleanliness}

New Urbanism strives for more coherence and beauty in the built environment more than is typical in most contemporary developments. It also strives for high standards of maintenance and cleanliness. In this it seeks to learn from the "timeless" values and principles of past urban design with their emphasis on pleasant public plazas, open vistas, and proportionality of open space to building height. Environmental psychology also addresses the importance of maintenance and esthetics. Although emerging from criminology not psychology, the "broken windows theory" of Kelling and Wilson (1982) states that allowing states of maintenance to slip in a community, such as tolerating broken windows and graffiti, will encourage more serious crime and disorder as they show a lack of care for the area. While the theory has been subject to criticism (see St. Martin, 2019) there is no doubt that a well-maintained and beautiful environment is essential for residents' sense of well-being. False
Creek South fulfils these requirements in that it is very wellmaintained, with minimal litter and a strong sense of civic pride.

\section{Architecture and Design}

New Urbanism places a strong emphasis on quality architecture and urban design. It seeks to avoid an overly homogenous design that is common in many standard subdivisions or condominium towers. Furthermore, human scale - an architectural principle that has been passed down through the ages - is vital for creating an environment where humans do not feel overwhelmed by their own creations. Environmental psychologists also favor a more ornate built form that is visually and psychologically stimulating. In this regard, both schools of thought tend to reject large, uninviting blank structures. Those psychologists and urban design researchers who have pioneered the field of participatory evaluation have discovered that members of the public tend to prefer pre-modernist architectural styles that offer more detail and that are closer to the human scale (Al-Kodmany, 1999; Preiser and Nasar, 2008).

\section{Mixed Uses and Diverse Building Types}

New Urbanists favor a diversity of building types: singledetached homes with coach houses, duplexes, rowhouses, stacked townhouses, walk-up apartments. When neighborhoods possess a large diversity of building types, it encourages diversity of residents and creates more inclusive environments. Environmental psychologists also favor a mix of building types and land uses as they reinforce walkability and access to amenities (see next sections). False Creek South has no single-family, duplex or coach house dwellings, which is appropriate given 
its central city location, but has a variety of other building types appropriate for an inner-city neighborhood, including townhouses and structures that border on high-rises that were added in the last phases of development. Some of its commercial service hubs have declined, but Granville Island remains a major node on its western end, and new commercial nodes have developed in the adjacent neighborhood of Southeast False Creek/Olympic Village, and along the Cambie Corridor.

\section{Walkability}

New Urbanism, in its reaction against the domination of our cities by motor vehicles, places a strong emphasis on walkability, arguing that major amenities (including transit lines) should be within 1,500 feet $(457 \mathrm{~m})$ of the furthest home. Environmental psychologists also place a strong premium on walkability with paths offering interesting vistas and everchanging environments. Both emphasize walking and cycling as active forms of transportation that contribute to physical health and stress release while offering opportunities for serendipitous encounters. False Creek South is very walkable and offers interesting paths and vistas (the original planning document called them "reference points"); cars do not dominate the neighborhood and have limited access.

\section{Amenities}

As mentioned, easy access to amenities is an important principle for New Urbanists, as it is for environmental psychologists. Amenities do not just include shopping. As Gifford (2014b) has noted, they also include schools, parks, and recreation facilities with which the neighborhood is well-endowed. While some of the original businesses have disappeared, Granville Island continues to exist, and additional amenities have appeared close by. The degree of mixed use is adequate but is not as woven into the fabric as New Urbanists would advocate. This is partly because the planners opted for a non-gridded style of development, which minimized the presence of cars but also made it more difficult to mix up land uses.

\section{Peace and Quiet}

This is not explicitly addressed in New Urbanism. While it advocates mixed use and lively streets, it does not adequately address the need for peace and quiet, at least at certain times of the day although, as it favors lower densities, this would tend to preclude high-intensity noise-producing activities. Environmental psychologists acknowledge that there needs to be a balance between liveliness in the built environment which encompasses some noise, and also quiet for human regeneration. It also notes that tolerance for noise varies by age group (Gifford, 2014b), with children being less affected than seniors. Being cut off from the rest of the City by water and a major arterial, False Creek South is for the most part quiet, excluding some enclaves and cul-de-sacs that function as noise amplifiers in a negative way.

\section{Feelings of Safety/Passive Surveillance}

This is not explicitly addressed in New Urbanism but is implicit in the notion of "eyes on the street" and 24/7 activity associated with mixed uses, an idea first pioneered by Jane Jacobs. Environmental psychologists see safety as an important measure of environmental quality as relates to how secure or, conversely, how anxious and fearful people feel. False Creek South is a safe neighborhood with minimal incidences of crime, apart from petty thefts that have been on the upswing in all parts of Vancouver in recent years (Howell, 2019).

\section{Resident Diversity}

New Urbanists seek diversity of people, housing, and densities. However, maintaining socio-economic (and, by extension, ethnic) diversity is harder to achieve given the tendency for property values to rise because of the quality of the resulting built environments (Litman, 2017). Environmental psychologists have had an ambivalent relationship with diversity, some of the earlier ones arguing that people find homogeneity of people and environments somewhat more comforting and less jarring, at least at a small scale (Michelson and Garland, 1974). This was partially reinforced in Vischer's (1986) study of the neighborhood, at least at a granular level. However, there is much to suggest, as evidenced by the large number of people choosing to repopulate inner-city neighborhoods, that people of all ages enjoy the vitality of dense mixed-use precincts, and even residents of False Creek South said they enjoyed urban diversity at larger scales (Vischer, 1986).

\section{FINDINGS AND CONCLUSION}

The planners and architects who created the principles used in the construction of False Creek South were forward-thinking. Their philosophy had much in common with that of today's New Urbanists and environmental psychologists. In comparing the neighborhood's features with the principles and prescriptions of New Urbanism and environmental psychology, we can see that there is considerable overlap between the two orientations. Although they share many commonalities, there are also some differences in their philosophies and application, such as New Urbanism putting more emphasis on civic infrastructure municipal and other civic buildings or monuments that provide focal points for neighborhoods. Both have an implicit orientation toward sustainability, but this is perhaps more developed in the case of New Urbanism where there is strong bias toward active transportation, which is facilitated through mixed use, and an embrace of renewable energy (more in theory than in practice). However, environmental psychology does seek to promote pro-environmental attitudes and behavior and highlights the importance of integrating the natural environment into everyday urban life.

While both favor outdoor spaces for socializing, are committed to pre- or post-modernist architecture and believe in the importance of high-quality pedestrian environments, New Urbanism has a stronger commitment to mixed use and environmental psychology tends to presume that residents prefer greater demographic homogeneity, and is more explicit about residents not being exposed to noxious adjacent land uses. New Urbanism is committed to socio-economic diversity but finds it 
hard to realize in practice due to the neighborhoods developed under its influence having high degrees of livability, which then tends to result in gentrification (Anonymous, 2009). False Creek South provides an example where representation of all income levels was built into the model from Day One and it has been relatively successful in adhering to that (City of Vancouver Planning Department, 2017; Alexander, 2020). This could be an important lesson for New Urbanists in the future.

Future work should focus on how each orientation can be made more robust by incorporating elements of the other's theory and practice. Also, in the future, we believe the "Patterns" documents of Thompson et al. (1974) are worthy of more intensive study, as they contain wisdom that could enrich both New Urbanism and environmental psychology. In addition, the significant contribution of participatory planning to the

\section{REFERENCES}

Alexander, C. (1969). Cells for Subcultures. Berkeley, CA: Center for Environmental Structure.

Alexander, C., Ishikawa, S., and Silverstein, M. (1978). A Pattern Language: Towns, Buildings, Construction. Oxford: Oxford University Press.

Alexander, D. (2020). Lessons of success: when planners get it right.

Al-Kodmany, K. (1999). Using visualization techniques for enhancing public participation in planning and design: process, implementation, and evaluation. Landsc. Urban Plann. 45, 37-45.

Anonymous, R. (2009). A Tale of Two (Segregated) Exurbs. Daily Kos. Available online at: https://www.dailykos.com/stories/2009/6/16/743073/-] (accessed July 15,2019$)$.

Ball, D. (2014). False Creek South: An Experiment in Community. Available online at: http://www.thesidewalkballet.com/2014/01/ (accessed July 15, 2019).

Brown, B., and Cropper, V. (2001). New urbanist and standard suburban subdivisions: evaluating psychological and social goals. J. Am. Plann. Assoc. 67, 402-419.

City of Vancouver Planning Department, (1989). Evaluation of False Creek South Social Objectives. Vancouver: City of Vancouver.

City of Vancouver Planning Department, (2017). False Creek South Community Profile 2017. Vancouver: City of Vancouver.

Congress for the New Urbanism and Talen, E. (2013). Charter of the New Urbanism. Vancouver, BC: McGraw-Hill Education.

Congress of New Urbanism, (n.d.). What is New Urbanism. Available online at: https://www.cnu.org/resources/what-new-urbanism (accessed July 15, 2019).

Garling, T. (2014). Past and present environmental psychology. Eur. Psychol. 19, 127-131. doi: 10.1027/1016-9040/a000184

Gifford, R. (2014a). Environmental psychology matters. Annu. Rev. Psychol. 65, 541-579.

Gifford, R. (2014b). Environmental Psychology: Principles and Practice, 5th Edn. Colville, WA: Optimal Books.

Gifford, R., Steg, L., and Reser, J. P. (2011). "Environmental psychology," in The IAAP Handbook of Applied Psychology, eds P. Martin, F. Cheung, M. Kyrios, L. Littlefield, M. Knowles, B. Overmier, et al. (New York, NY: Oxford), 440-470.

Griffin, K. (2019). Swimming Advisories in Effect at Two Metro Vancouver Beaches. Available online at: at https://vancouversun.com/health/local-health/ swimming-advisories-in-effect-at-two-metro-vancouver-beaches (accessed July 15, 2019).

Hardwick, W. G. (1994). Responding the 1960s: designing adaptable communities in vancouver. Environ. Behav. 26, 338-362.

Howell, M. (2019). Break-Ins to Cars in Vancouver Almost Double in 8 years: An Average of 40 Vehicles Per Day Were Broken into Per Day in 2018. Available online at: https://www.vancourier.com/news/break-ins-to-cars-in-vancouveralmost-double-in-eight-years- 1.23639109 (accessed July 15, 2019). ultimate design and success of the neighborhood needs to be acknowledged and made a more foundational part of both New Urbanism and environmental psychology. In the former case, it is paid lip service to but rarely practiced. In environmental psychology it has rarely gone beyond participatory evaluation of structures. As co-designer and architect, King (2020) emphasizes, it must go beyond that to people envisioning how they want to live and the activities they wish to engage in.

\section{AUTHOR CONTRIBUTIONS}

DA conceived of the idea for the manuscript and wrote two drafts. BW conducted background research and provided substantive editing and copy-editing, contributing to subsequent drafts.

Kelling, G., and Wilson, J. (1982). Broken Windows: The Police and Neighbourhood Safety. Available online at: https://www.theatlantic.com/magazine/archive/ 1982/03/broken-windows/304465/ (accessed July 15, 2019).

Kim, J., and Kaplan, R. (2004). Physical and psychological factors in sense of community: new urbanist kentlands and nearby orchard village. Environ. Behav. 6, 313-340.

King, S. (2020). Personal communication.

Litman, T. (2017). Gentrification, for Better and Worse. Planetizen (blog post). Available online at: https://www.planetizen.com/node/92831/gentrificationbetter-and-worse (accessed July 15, 2019).

Michelson, W., and Garland, K. (1974). The Differential Role of Crowded Homes and Dense Residential Areas in The Incidence of Selected Symptoms of Human Pathology. Toronto: Centre for Urban and Community Studies, University of Toronto.

New Urbanism, (n.d.). Planning Principles of New Urbanism. Available online at: http://www.newurbanism.org/newurbanism/principles.html (accessed July 15, 2019).

Preiser, W., and Nasar, J. (2008). Assessing building performance: its evolution from post-occupancy evaluation. Int. J. Arch. Res. 2, 84-99.

St. Martin, G. (2019). Researchers find Little Evidence for 'Broken Windows Theory,' Say Neighborhood Disorder Doesn't Cause Crime. Available online at: https://phys.org/news/2019-05-evidence-broken-windows-theoryneighborhood.html/ (accessed July 15, 2019).

Thompson, B., Pratt, B., and Partners for the City of Vancouver Planning Department, (1974). False Creek Proposals, Working Papers: Vol. 1, Patterns.

Vancouver Magazine, (2016). Vancouver's Best Neighbourhoods 2016: our firstever data-driven ranking of this city's best places to live. Available online at: http://vanmag.com/best-of-the-city/vancouvers-best-neighbourhoods-2016/ (accessed July 15, 2019).

Vischer, J. (1986). Social mix and environmental design: exploration of a contemporary concept. J. Arch. Plann. Res. 11, 315-326.

Vischer Skaburskis Planners, (1980). False Creek Area 6 Phase 1 Post-Occupation Evaluation (2 vols.). Ottawa: Canada Mortgage and Housing Corporation.

Conflict of Interest: The authors declare that the research was conducted in the absence of any commercial or financial relationships that could be construed as a potential conflict of interest.

Copyright (c) 2020 Alexander and Wydeman. This is an open-access article distributed under the terms of the Creative Commons Attribution License (CC BY). The use, distribution or reproduction in other forums is permitted, provided the original author(s) and the copyright owner(s) are credited and that the original publication in this journal is cited, in accordance with accepted academic practice. No use, distribution or reproduction is permitted which does not comply with these terms. 